\title{
ANALYSIS OF ORGANIZATIONAL CULTURE DIMENSIONS IMPACTING PERFORMANCE
}

\author{
Romualdas Ginevičius ${ }^{1}$, Vida Vaitkūnaitè ${ }^{2}$ \\ Vilnius Gediminas Technical University, Saulètekio al. 11, LT-10223 Vilnius, Lithuania \\ E-mail: 'romualdas.ginevicius@adm.vtu.lt, ${ }^{2} v$ vaitkun@yahoo.com \\ Received 15 June 2006; accepted 10 October 2006
}

\begin{abstract}
The paper reveals multidimensional nature of organizational culture. When investigating its influence on success only performance influencing dimensions must be under consideration. The authors suggest the ways for reducing their number: content analysis and hierarchical structuring method. The system (list) of dimensions was formed by using the mentioned methods. Questionnaire was made. Relationship between dimensions and their influence on performance was tested.
\end{abstract}

Keywords: organizational culture, dimensions, influence, performance, relationship, assessment.

\section{Introduction}

The Organizational culture (OC) is a complex phenomenon, which is characterized by many aspects (dimensions) [1]. OC research can be divided into three groups. The first group embraces scientific works, in which culture is only described [2-4]. The second one includes works, in which dimensions are picked out [5-7]. Their influence on success is validated theoretically or empirically in the third group of works [1, 8-14]. The more dimensions of the analysed phenomenon will be disclosed, the more clearly it will be perceived. However, analysing all dimensions is irrational when investigating culture's influence on success, i.e. only selection of the performance most influencing dimensions is significant. If we know the influence of each dimension, we can "correct" them. Thus, we can manage the performance.

Scientists, who analyse OC, present different number of dimensions. Furthermore, some of them are very similar by their content (meaning), i.e. they are components of each other. Not all scientists examine the link between dimensions and organizational outcomes.
Therefore the goal of this paper is to pick out significant, performance influencing dimensions; to examine interrelationship between them and their influence on performance.

The research methods, used in this work, are systematic analysis of scientific literature, content analysis, method of hierarchical structuring, correlation and factor analysis.

\section{Assessment of organizational culture}

The phenomenon, observed in organizations, called as organizational culture, was primarily analysed only by using qualitative research methods. It was considered not to be measured, therefore when compared with organizational climate, the different measurement methods were distinguished as the biggest difference between them, i.e. climate can be measured quantitatively and OC can be assessed only qualitatively [15, 16]. When the influence of OC on performance was noted, it was sought for the quantitative evaluation methods of OC as well. The first step to the quantitative assessment was the perception, that some aspects 
(dimensions) can be separate in the OC. The second step was creation of questionnaire, in which statements characterizing dimensions are presented (see Appendix). Respondents evaluate whether they are characteristic to their enterprise or not. The scientist gives the quantitative expression for the answers. 5-point Likert scale is chosen the most often $[5,10,11,14,17]$. Based on it the answers from "Strongly disagree" to "Strongly agree" are expressed correspondingly in numbers 15. After analysing answers of respondents, various aspects of OC can be assessed.

The questionnaire of measurement (assessment) of OC is called a research instrument $[5,14,16,18,19]$ or tool [20]. It can be useful for both practical and scientific purposes. In the first case, enterprises are interested to investigate their cultures, because they want: 1) to diagnose the $\mathrm{OC}$ and find problematic areas, which can cause problems in the future, if they are not "corrected"; 2) to establish the benchmarking position; 3) to manage the changing OC [20]. Management of OC of merged and acquired companies is especially important [3].

Scientists try to compare the impact of OC on success (performance) in different enterprises. They can be grouped into different groups according to size [14, $19,21,22]$, age $[21,22]$, industry $[17,21]$, country
$[11,21]$, life cycle phase, and activity type (services, manufacture). Comparative analysis can show, which dimensions are the most important (the most influencing performance) in different groups.

Usually OC measurement concept is used in the literature. However, members of enterprise assess OC (to be precise, its dimensions). This assessment is subjective. Therefore assessment concept is more suitable than measurement. Measurement is usually expressed in objective measures such as financial ratios in finance and so on. So, the measurement is associated with objectivity, and assessment - with subjectivity.

Table 1 presents lists of dimensions of $\mathrm{OC}$ research instruments. Different authors present different number of dimensions. Furthermore, they are similar by their content; therefore it is unclear if they are the same or different dimensions. For example, Park [24] treats teamwork and participation (involvement) as single (separate) dimensions of OC. Denison and Neale [20] ascribe teamwork to involvement dimension. After analysing literature, in which OC is only described but concrete dimensions are not picked out, it becomes clear, that there are more cultural aspects. Therefore dimensions of OC must be reanalysed. This will help to decide, whether they can be involved into research instrument of $\mathrm{OC}$ or not.

Table 1. Dimensions, presented in instruments of organizational culture measurements

\begin{tabular}{|c|c|c|}
\hline Name of instrument & Dimensions of organizational culture & Notes \\
\hline $\begin{array}{l}\text { Denison Organizational } \\
\text { Culture Survey [20] }\end{array}$ & $\begin{array}{l}\text { 1) involvement: a) empowerment, b) team orientation, c) capability development; } \\
\text { 2) consistency: a) core values, b) agreement, c) coordination and integration; } \\
\text { 3) adaptability: a) creating change, b) customer focus, c) organizational learning; } \\
\text { 4) mission: a) strategic direction and intent, b) goals and objectives, c) vision }\end{array}$ & $\begin{array}{l}\text { Relationship between } \\
\text { dimensions and measures of } \\
\text { effectiveness are examined } \\
\text { empirically }\end{array}$ \\
\hline $\begin{array}{l}\text { An instrument to } \\
\text { measure organizational } \\
\text { culture [5] }\end{array}$ & $\begin{array}{l}\text { 1) conflict resolution, 2) culture management, 3) customer orientation, 4) disposition } \\
\text { towards change, 5) employee participation, 6) goal clarity, 7) human resource } \\
\text { orientation, 8) identification with the organization, 9) locus of authority, } \\
\text { 10) management style, 11) organization focus, 12) organization integration, } \\
\text { 13) performance orientation, 14) reward orientation, 15) task structure }\end{array}$ & $\begin{array}{l}\text { Authors picked out } 114 \\
\text { dimensions. This number was } \\
\text { decreased to } 15 \text { after analysis. } \\
\text { Dimensions are linked with } \\
\text { financial performance [23] }\end{array}$ \\
\hline $\begin{array}{l}\text { Perceived Cultural } \\
\text { Compatibility Index [6] }\end{array}$ & $\begin{array}{l}\text { 1) encourages creativity and innovation, 2) cares about health and welfare of } \\
\text { employees, 3) is receptive to new ways of doing things, 4) is an organization people } \\
\text { can identify with, 5) stresses team work among all departments, 6) measures individual } \\
\text { performance in a clear, understandable manner, 7) bases promotion primarily on } \\
\text { performance, 8) gives high responsibilities to managers, 9) acts in responsible manner } \\
\text { towards environment, discrimination, etc., 10) explains reasons for decisions to } \\
\text { subordinates, 11) has managers who give attention to individual's personal problems, } \\
\text { 12) allows individuals to adopt their own approach to job, 13) is always ready to take } \\
\text { risks, 14) tries to improve communication between departments, 15) delegates } \\
\text { decision-making to lowest possible level and other ones }\end{array}$ & $\begin{array}{l}\text { Totally } 23 \text { items. Authors think } \\
\text { that selected dimensions are } \\
\text { linked with performance. } \\
\text { Instrument was created to assess } \\
\text { merged companies }\end{array}$ \\
\hline $\begin{array}{l}\text { Critical success and } \\
\text { failure factors of } \\
\text { organizational culture } \\
\text { change [24] }\end{array}$ & $\begin{array}{l}\text { 1) communication, 2) leadership, 3) employee participation, 4) HRM training and } \\
\text { development, 5) improvements in teamwork, 6) regular feedback, 7) continuous } \\
\text { change, 8) organization structure, 9) empowerment, 10) creativity and other ones }\end{array}$ & $\begin{array}{l}\text { Dimensions are linked with } \\
\text { changes of organizations }\end{array}$ \\
\hline $\begin{array}{l}\text { Organizational Culture } \\
\text { Profile [7] }\end{array}$ & $\begin{array}{l}\text { 1) competitiveness, 2) social responsibility, 3) supportiveness, 4) innovation, } \\
\text { 5) emphasis on rewards, 6) performance orientation, 7) stability }\end{array}$ & $\begin{array}{l}\text { Authors provide an improved } \\
\text { O'Reilly's, Chatman's and } \\
\text { Caldwell's instrument version. } \\
\text { An empirical evidence about the } \\
\text { link between dimensions and } \\
\text { performance is not given }\end{array}$ \\
\hline
\end{tabular}




\section{Analysis of dimensions of organizational culture}

Definitions of organizational culture disclose diverse, often different aspects of it. Schein [2] provided one of the most exhaustive definitions. According to the author, organizational culture is a pattern of shared basic assumptions, which are formed, when members of organization solve the problems of external adaptation and internal integration. These assumptions are taken for granted, however it is very difficult to observe them [2]. They are linked with employees' behaviour, which is easier to observe [25]. So, namely behaviour should be analysed when investigating OC.

Organizational culture can be described by its aspects [3], dimensions [5, 16, 18], traits [10], elements [18, 22, 26]. Scientists use different concepts. However, after analysing their works, it became clear, that these concepts have the same meaning. So, these concepts (dimensions, aspects, etc.) characterize OC and show that it is not single, and various aspects can be observed in it as well.

When seeking to assess different phenomena, the question arises - how many factors can disclose them. The choice of improper number can cause such problems [27]: 1) if number of factors is insufficient, the reality won't be disclosed exhaustively, 2) if there are too many factors, the problem will be complex.

The selection of OC dimensions was carried out in three stages:

1. All dimensions were collected from the sources of literature. Many authors didn't single out concrete dimensions; therefore by analysing the content of described phenomena names characterising cultural aspects were given for them.

2. Differently named dimensions were ascribed to one dimension, if after analysing their content it became clear, that they were similar.

3. Only such dimensions were selected, impact of which on performance was based empirically or theoretically.

Totally 53 works were analysed. They revealed not only aspects of organizational culture, but also changes of it and behaviour of employees. References of the authors [5, 6, 24], who also made the list of dimensions by analysing other works, were not examined in this paper. So, it is possible to say that duplication of dimensions was avoided. It is important because the frequency is given near them. The results of analysis are presented in Table 2. Only such dimensions were included in it, influence of which was validated. The number of authors, who tested this influence, is presented in brackets. The asterisk means, that one author based the link only theoreti-

Table 2. Dimensions of organizational culture

\begin{tabular}{|c|c|c|}
\hline Name of dimension & Different names by authors & $\begin{array}{c}\text { Frequency of } \\
\text { dimension }\end{array}$ \\
\hline 1 & 2 & 3 \\
\hline 1. Communication & \$ Communication $[1,3-6,8,13,14,19,22,24,26,28-44]$ & $29(6)$ \\
\hline 2. Management style & $\begin{array}{l}\$ \text { Management style }[4,5,8,9,11,24,31,34,35,40,41,45-50] \\
\$ \text { Leadership [36, 39, 42, 51, 52] } \\
\text { \$ Management, support 29] } \\
\$ \text { Management practice 53] } \\
\text { \$ Strength of management [16] }\end{array}$ & $25(4)$ \\
\hline $\begin{array}{l}\text { 3. Reward and incentive } \\
\text { system }\end{array}$ & $\begin{array}{l}\$ \text { Pay and incentive system }[41] \\
\$ \text { Reward and punishment system }([2,5] \\
\$ \text { Reward }[4,7,24,28,31,35,47,48,51,56] \\
\$ \text { Propriety criteria of compensation }[1] \\
\$ \text { Support [36] }\end{array}$ & $23(2)$ \\
\hline 4. Decision making & \$ Decision making $1-3,5,6,9,10,14,18,28,30,33,34,38,41,44,45,47,48,50,55,57]$ & $22(6)$ \\
\hline 5. Strategy and goals & $\begin{array}{l}\$ \text { Strategy and goals }[1,2,10,28] \\
\$ \text { Goals }[4,5,13,31,36-38,41,42,52,54,55] \\
\$ \text { Strategy }[3,33,44,47] \\
\$ \text { Long term programme }[6,24]\end{array}$ & $22(3)$ \\
\hline 6. Cooperation (collaboration) & $\begin{array}{l}\$ \text { Cooperation }[3,5,10,14,17,38,41,45] \\
\$ \text { Team work }[6,7,16,24,30,35,43,56,58] \\
\$ \text { Behaviour between employees }[57] \\
\$ \text { Type of interpersonal relationships }[4,40] \\
\$ \text { Integration of members of organization into team }[42]\end{array}$ & $21(6)$ \\
\hline $\begin{array}{l}\text { 7. Coordination and } \\
\text { integration }\end{array}$ & $\begin{array}{l}\$ \text { Coordination and integration }[2,3,5,10,13,14,17,19,28,29,31,32,37,39,41,54,55,48] \\
\$ \text { Cohesion of groups }[59] \\
\$ \text { Group interaction }[40] \\
\$ \text { Relationships between hierarchical levels and subgroups [43] }\end{array}$ & $21(5)$ \\
\hline 8. Innovations & $\begin{array}{l}\$ \text { Innovations }[1,6,8,14,16,41,44,48,51,56] \\
\$ \text { Creating change }[5,10,24] \\
\$ \text { Risk }[7,28,37,42,47,50,58]\end{array}$ & $20(7)$ \\
\hline
\end{tabular}


Table 2 continued

\begin{tabular}{|c|c|c|}
\hline 1 & 2 & 3 \\
\hline 9. Adaptation & $\begin{array}{l}\$ \text { Adaptation }[2,8,10,14,18,19,24,28,30,31,38,42,47,51,55,57,50] \\
\$ \text { Management of changes }[44] \\
\$ \text { Response to the market }[1]\end{array}$ & $19(10)^{*}$ \\
\hline 10. Learning & $\begin{array}{l}\$ \text { Learning/ training }[5,10,13,19,24,30,31,35,41,44,45,47,49] \\
\$ \text { Skills (competence) [2] } \\
\$ \text { Human resource development and training [50] } \\
\$ \text { Professionalism [1] } \\
\$ \text { Career [55] } \\
\text { \$ Knowledge [34] } \\
\text { \$ Managers improvement [43] }\end{array}$ & $19(5)$ \\
\hline 11. Norms, rules and values & $\begin{array}{l}\$ \text { Norms, rules and values }[2,5,41,42,51,54] \\
\$ \text { Values }[10,16,33] \\
\$ \text { Rules }[3,31,37,38] \\
\$ \text { Standards of group }[35] \\
\text { \& Normative documents }[4] \\
\text { \& Degree of formality }[47,50]\end{array}$ & $17(3)^{*}$ \\
\hline 12. Organizational structure & $\begin{array}{l}\text { \$ Organizational structure }[1-3,8,24,31,38,40,41,45,47,50,53,54] \\
\$ \text { Management structures [9] } \\
\$ \text { Number of hierarchical levels [33] } \\
\$ \text { Infrastructure [34] }\end{array}$ & $17(2)$ \\
\hline $\begin{array}{l}\text { 13. Behaviour with subjects of } \\
\text { external environment (e.g. } \\
\text { clients) }\end{array}$ & $\begin{array}{l}\text { \$ Behaviour with subjects of external environment }[6,14,38,43,47,50,54] \\
\$ \text { Interaction policy }[45] \\
\$ \text { Care about client }[4,5,10,22 ; 31,51] \\
\$ \text { Social responsibility }[7,57]\end{array}$ & $16(4)$ \\
\hline 14. Climate & $\begin{array}{l}\$ \text { Climate }[1,2,4,8,22,34,36,39,41,43] \\
\$ \text { Work environment }[47,50] \\
\$ \text { Atmosphere }[5,31,35,38]\end{array}$ & $16(3)$ \\
\hline 15. Mechanism of control & $\begin{array}{l}\$ \text { Control mechanism }[2,19,29,31,33,37,38,45,47,50,55] \\
\$ \text { Control of management }[14,41,42]\end{array}$ & $14(2)$ \\
\hline 16. Involvement & $\begin{array}{l}\text { \$ Involvement }[1,5,10,13,18,22,45,49] \\
\$ \text { Participation }[24,35,43,51] \\
\end{array}$ & $13(7)$ \\
\hline 17. Transmission of information & $\begin{array}{l}\$ \text { Systems of information }[2,3,7,10,31,32,41,44,45,47,50] \\
\$ \text { Process of knowledge transmission }[54]\end{array}$ & $12(1)$ \\
\hline 18. Concern for employees & $\begin{array}{ll} & \text { Concern for employees }[1,5,6,7,14,41,51,55] \\
\$ \text { Support of managers }[16,37] \\
\$ \text { Work/ family programs }[43]\end{array}$ & $11(3)$ \\
\hline 19. Agreement & $\begin{array}{l}\$ \text { Agreement }[2,4,7,10,34,43,59] \\
\$ \text { Conflicts }[5,37,47,54]\end{array}$ & $11(1)$ \\
\hline $\begin{array}{l}\text { 20. Degree of employees' } \\
\text { responsibility and freedom }\end{array}$ & $\begin{array}{l}\$ \text { Degree of employees' responsibility, freedom and independence }[5,37] \\
\$ \text { Taking over of responsibility }[7,28,45,55] \\
\$ \text { Degree of freedom }[1,38,40] \\
\$ \text { Responsibility of managers }[6,42]\end{array}$ & $11(1)$ \\
\hline 21. Empowerment & $\begin{array}{l}\text { \$ Delegation }[2,13,35,45] \\
\$ \text { Empowerment }[5,6,10,24,41 ; 43]\end{array}$ & $10(3)$ \\
\hline $\begin{array}{l}\text { 22. System of selection of } \\
\text { employees }\end{array}$ & $\begin{array}{l}\text { \$ System of selection }[1,3,34,41,43,49] \\
\$ \text { Process of group formation, boundaries of membership in organization [2] } \\
\text { \$ Stability of subordination to the group [54] } \\
\text { \$ Policy of personnel [4] }\end{array}$ & $9(1)$ \\
\hline 23. Vision & $\begin{array}{l}\text { \& Vision }[5,10,13,24 ; 38,44,52] \\
\$ \text { Direction }[34]\end{array}$ & $8(1)$ \\
\hline 24. Mission & $\$$ Mission $[2,5,10,24,38,41]$ & $6(1)$ \\
\hline 25. Politics of enterprise & $\$$ Politics $[1,5,38]$ & $3(1)$ \\
\hline
\end{tabular}

cally. Dimensions are laid out in Table 2 in descending manner of frequency. In addition, it is presented, how different authors name dimensions or which aspects are analysed in their works.

The number in brackets (see Table 2) only shows, how many authors analysed these aspects of OC by relating them with performance, but it does not mean that they have strong link with organizational outcomes.
In general, frequency of mention of each dimension is significant and shows, how many scientists noted namely this aspect by analysing OC. Graphic view of distribution (arrangement) of dimensions according to significance is presented in Fig 1.

Upper curve shows frequency of mention of dimension. Lower curve shows how many scientists found relationship between certain dimensions and performance. 


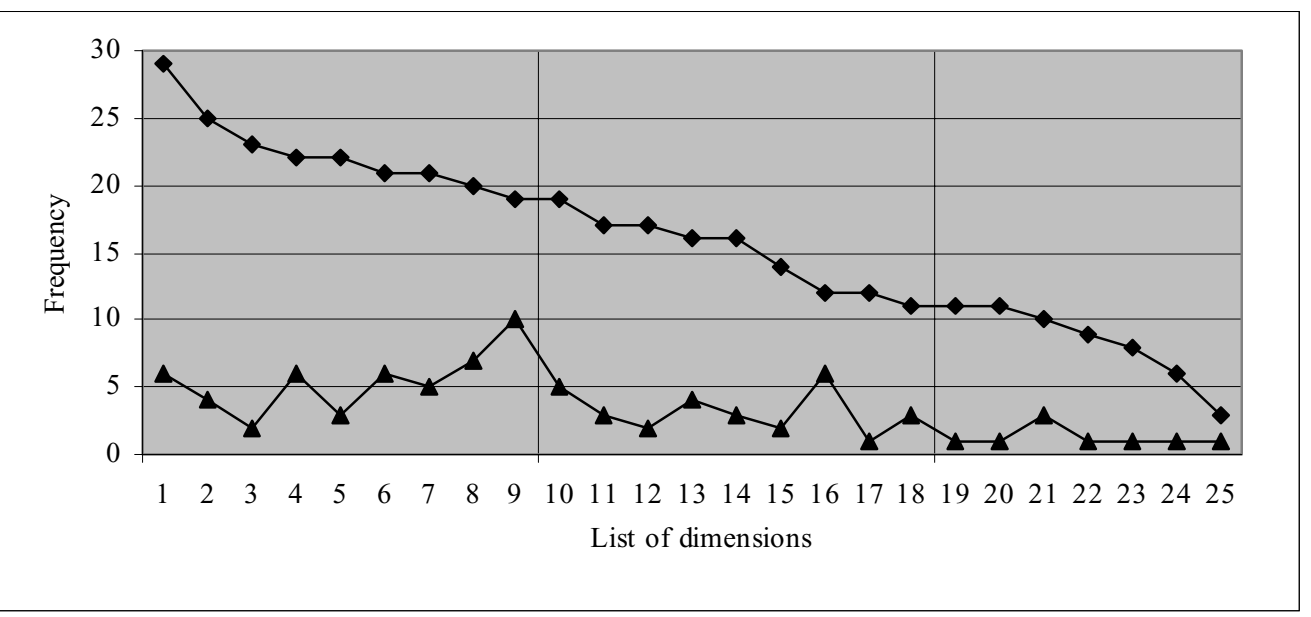

Fig 1. Distribution of frequency of dimensions of organizational culture

Dimensions in Fig 1 are distributed into three areas of significance according to Ginevičius and Podvezko [27] method of distribution of phenomenon factors. Based on this method experts assess the list of factors, then by using mathematical counting the most significant factors are picked out. The first area shows the most significant factors, the second one shows factors, which have a medium influence on phenomenon, the third one shows insignificant criteria or such criteria, which have little influence on phenomenon.

The authors presented in Table 2 analysed different number of dimensions. Some of them analysed only the chosen area, e.g. Horwitz at al. [13] examined influence of human resources on performance. So, the number of evaluators for each dimension was different. Lack of information hinders to use all the advantages of the mentioned method. However, general tendency can be disclosed - if many authors analysed the same dimension, it is probable, that this dimension is important, especially if it is linked with organizational outcomes.

In case it was tried to attribute the aspects of the same content to the same dimension, not all dimensions have still the same extent. In other words, many dimensions are similar by content (meaning). Such situation appeared because some authors presented some aspects as separate ones, although they can be joined into one.

Only dimensions, marked with grey colour (see Table 2), can be included into the research instrument (questionnaire), because they are monosemantic. The remaining dimensions have double dependencies; therefore only they will be analysed further. Content analysis [60] and hierarchical structuring method [61] were used for seeking to eliminate double relationship and to decrease the number of dimensions. Content analysis is such method, when there are analysed words, which describe the investigated phenomenon. Content of dimensions was analysed by examining description of dimensions, provided by authors presented in Table 2 . Relationship between concepts was established according to mentioned descriptions. The essence of hierarchical structuring method is that the analysed phenomenon is presented graphically and matrix is made, where relationship between dimensions of phenomenon is presented. The number of relationship is decreased by successive comparison.

Relationship between dimensions, which have double dependencies, is presented in Fig 2. Organizational climate, system of selection and politics of enterprise are not presented in Fig 2. Organizational climate is a separate phenomenon, although it is associated with OC [15], so it should be analysed separately. Selection system is not a daily phenomenon in organization, so it can be insignificant for some enterprises, especially if turnover is low. Enterprise politics according to Fig 1 is the least significant dimension. So, it was rejected.

We can see from Fig 2, that management style is defined by 8 dimensions: delegation of tasks and competence (empowerment), decision making, involvement, support (concern) for employees, control [5, 45], communication style between managers and subordinates [5], responsibility and freedom of employee (influence) [5, 41, 42, 50] and turn for innovations [8]. If we used management style dimension, it would be too broad, therefore broader class must be refused and smaller one must be used. However, these smaller dimensions not only define management style, but also are components of each other. For example, involvement is defined by participation in decision-making process $[1,5,10,12,41,45,47,50]$, decision making 


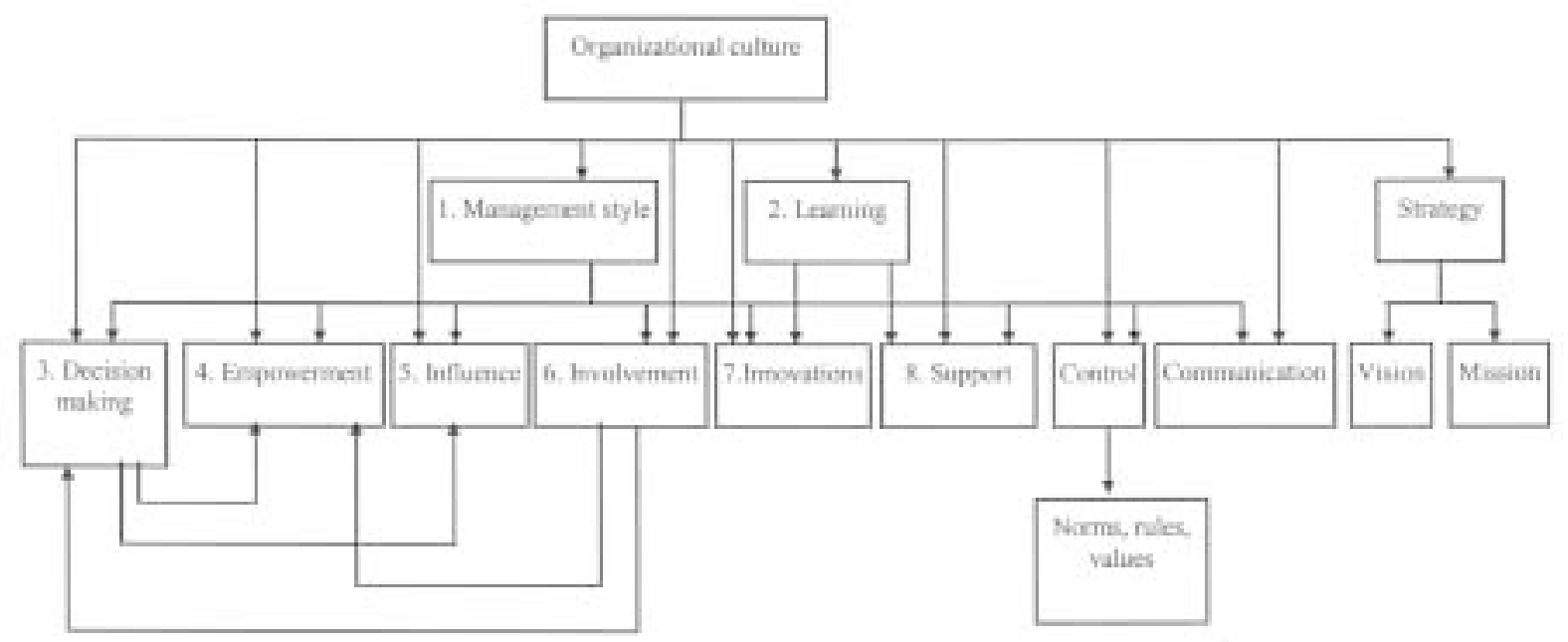

Fig 2. Hierarchical structure of dimensions

is associated with empowerment $[2,5,6]$ and so on. Double dependencies between such dimensions must be removed.

If we refuse the management style dimension, control and communication become independent units, i.e. double relationship disappears. After ascribing vision and mission to strategy, only it can be kept in the list of dimensions. Relationship between remaining dimensions is complex. Based on the method offered by Ginevičius [61] they are numerated and presented in matrix form (see Fig 3). By seeking to arrange matrix $\mathrm{M}_{1}$, reverse relationship which is marked as "-", and double-relationship between dimensions must be eliminated.

Relationships are corrected by using the mentioned method [61]. They are presented in Fig 4.

\begin{tabular}{|c|c|c|c|c|c|c|c|c|}
\hline & 1 & 2 & 3 & 4 & 5 & 6 & 7 & 8 \\
\hline 1 & & 0 & + & + & + & + & + & + \\
\hline 2 & 0 & & 0 & 0 & 0 & 0 & + & + \\
\hline 3 & - & 0 & & + & + & - & 0 & 0 \\
\hline 4 & - & 0 & - & & 0 & - & 0 & 0 \\
\hline 5 & - & 0 & - & 0 & & 0 & 0 & 0 \\
\hline 6 & - & 0 & + & + & 0 & & 0 & 0 \\
\hline 7 & - & - & 0 & 0 & 0 & 0 & & 0 \\
\hline 8 & - & - & 0 & 0 & 0 & 0 & 0 & \\
\hline
\end{tabular}

Fig 3. Matrix $\mathrm{M}_{1}$ of coherent comparison of dimensions

\begin{tabular}{|c|c|c|c|c|c|c|c|c|}
\hline & 1 & 6 & 3 & 4 & 5 & 2 & 7 & 8 \\
\hline 1 & & $\oplus$ & + & + & + & 0 & + & + \\
\hline 6 & & & $\oplus$ & + & + & 0 & 0 & 0 \\
\hline 3 & & & & $\oplus$ & $\oplus$ & 0 & 0 & 0 \\
\hline 4 & & & & & 0 & 0 & 0 & 0 \\
\hline 5 & & & & & & 0 & 0 & 0 \\
\hline 2 & & & & & & & $\oplus$ & $\oplus$ \\
\hline & & & & & & & + & 0 \\
\hline 7 & & & & & & & & \\
\hline
\end{tabular}

Fig 4. Modified matrix $\mathrm{M}_{1}$
Fig 5 is drawn according to corrected matrix.

As it was mentioned, management style will not be included into the list of OC dimensions. After refusing it, double relationship, which linked it with innovations and support, disappears (see Fig 5). Now they belong to the learning dimension. Namely it (not its components) will be included into the list. Grey coloured dimensions (see Fig 5) are included into the list; remaining ones will be reflected in them.

Analysis, made in this paper, allows to form such list of dimensions: 1) involvement, 2) cooperation (collaboration), 3) transmission of information, 4) learning, 5) care about clients, 6) adaptability, 7) strategic direction, 8) reward and incentive system, 9) system of control, 10) communication, 11) agreement, 12) coordination and integration.

Although organizational structure is significant it is not included in many OC assessment instruments because more complex than questionnaire research

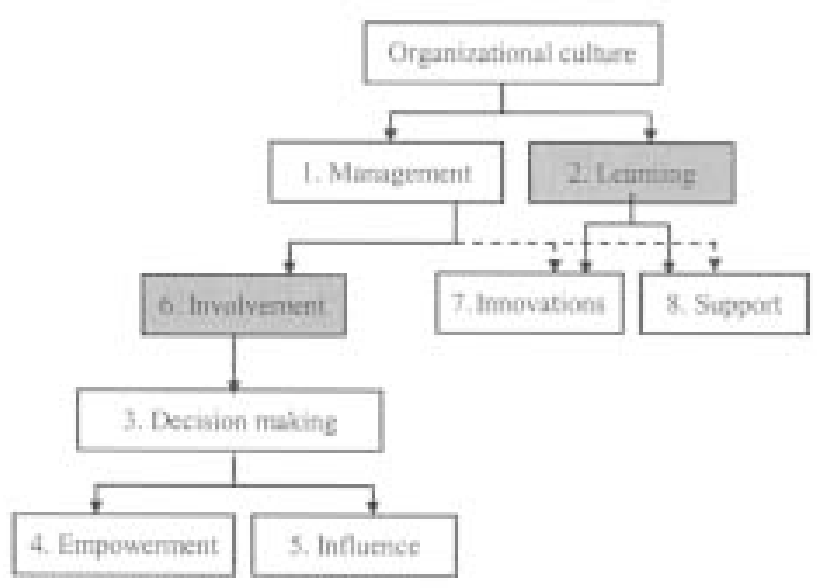

Fig 5. Corrected relationships between dimensions 
methods are needed to disclose its essence. In this paper it is not included in the questionnaire because of mentioned reason. Furthermore, dimensions are characterized by statements, which disclose behaviour of employees. Organizational structure is ascribed to artefacts [2]; therefore it would be distinguished from the set of other dimensions.

If we compare the number of dimensions with other authors lists of ones (see Table 1), we will note, that Denison and Neale [20] presented the same number of dimensions, but they differ. Other authors present not only different dimensions, but also different number of dimensions.

\section{Relationship between dimensions of organizational culture}

By seeking to examine the interrelationships between dimensions, a questionnaire was made. Statements were formulated to disclose the essence of them (see Appendix). The statements of other authors were under consideration [20]. As it was mentioned, some dimensions are components of other ones. This was under consideration when formulating statements too. Thus, smaller dimensions do not disappear, they just "hide themselves" in other ones. Such number of statements was used for describing dimensions, which can disclose their essence in the best way. It was striven to formulate more positive statements than negative ones.

Questionnaires were presented to 334 Lithuanian companies. 73 companies refused to participate in survey. Remaining ones filled in 23 questionnaires. So, such survey can be called only pilot study, which can show whether questionnaire is suitable to use in further investigations.

Respondents had to choose an answer from "strongly disagree" to "strongly agree". Later these answers were transformed into 1-5 points. 4 top-level managers, 7 middle-level managers and 12 subordinates participated in survey. Since there was one respondent from each enterprise, he/ she was asked to assess each statement not personally, but on behalf of many employees. Literature recognizes single respondent survey too [21]. However, incongruity of opinions can remain. Another problem - firms are from different industries and their sizes are different; therefore answers can be distributed very differently. Survey results are presented in Table 3.

Table 3 shows, that dimensions are interrelated. According to the research results, the most correlated dimensions are: adaptability with care about clients and transmission of information, reward and incentive with learning and strategic direction, communication with reward, agreement with transmission of information, coordination and integration with agreement. Most dimensions are correlated with communication, reward and incentive.

As there are related dimensions, it is possible that they form broader classes of dimensions. Factor analysis is usually used for such grouping. It also shows the validity of questionnaire. This analysis could not be used for the examination of all statements because there were few respondents. It was used in this work only for grouping the mentioned dimensions. Results of analysis are presented in Table 4.

The Table 4 presents correlations between dimensions after Varimax rotation. Dimensions can be grouped into four groups. The first group is directed toward outside (clients), the third one defines work style, the fourth one is associated with organizational systems (reward, information and so on). The second one is directed toward concern about employees. However, strategic direction gets into it too. Its content differs from other dimensions. This states, that more respondents should be involved to define these groups more exactly.

Table 3. Pearson correlation of dimensions of organizational culture $(\mathrm{N}=23)$

\begin{tabular}{|c|c|c|c|c|c|c|c|c|c|c|c|c|c|c|}
\hline Dimension & Mean & S.D. & 1 & 2 & 3 & 4 & 5 & 6 & 7 & 8 & 9 & 10 & 11 & 12 \\
\hline 1. Involvement & 3,86 & 0,52 & 1 & & & & & & & & & & & \\
\hline 2. Cooperation (collaboration) & 3,91 & 0,50 & 0,38 & 1 & & & & & & & & & & \\
\hline 3. Transmission of information & 3,79 & 0,51 & 0,03 & 0,08 & 1 & & & & & & & & & \\
\hline 4. Learning & 3,55 & 0,68 & 0,14 & 0,33 & 0,39 & 1 & & & & & & & & \\
\hline 5. Care about clients & 3,94 & 0,61 & 0,26 & 0,24 & 0,51 & 0,40 & 1 & & & & & & & \\
\hline 6. Adaptability & 3,77 & 0,59 & 0,13 & 0,21 & 0,70 & 0,45 & 0,70 & 1 & & & & & & \\
\hline 7. Strategic direction & 3,89 & 0,59 & $-0,10$ & 0,00 & 0,22 & 0,54 & 0,30 & 0,04 & 1 & & & & & \\
\hline 8. Reward and incentive system & 3,56 & 0,58 & 0,22 & 0,30 & 0,40 & 0,58 & 0,49 & 0,28 & 0,56 & 1 & & & & \\
\hline 9. System of control & 3,63 & 0,38 & 0,35 & $-0,12$ & 0,40 & $-0,13$ & 0,31 & 0,30 & $-0,23$ & 0,07 & 1 & & & \\
\hline 10. Communication & 3,98 & 0,39 & 0,39 & 0,25 & 0,49 & 0,40 & 0,48 & 0,48 & 0,32 & 0,68 & 0,19 & 1 & & \\
\hline 11. Agreement & 3,64 & 0,27 & 0,31 & 0,29 & 0,55 & 0,37 & 0,46 & 0,39 & 0,27 & 0,32 & 0,40 & 0,44 & 1 & \\
\hline 12. Coordination and integration & 3,76 & 0,69 & 0,52 & 0,40 & 0,49 & 0,17 & 0,26 & 0,29 & 0,09 & 0,03 & 0,47 & 0,37 & 0,56 & 1 \\
\hline
\end{tabular}


Table 4. Factor analysis of dimension of OC $(\mathrm{N}=23)$

\begin{tabular}{|l|r|r|r|r|}
\hline Dimension & \multicolumn{1}{|c|}{ F1 } & F2 & \multicolumn{1}{c|}{ F3 } & \multicolumn{1}{c|}{ F4 } \\
\hline 1. Involvement & 0,031 & 0,041 & $\mathbf{0 , 6 5 9}$ & 0,500 \\
2. Cooperation & 0,095 & 0,130 & $\mathbf{0 , 9 8 0}$ & $-0,003$ \\
3. Information system & 0,409 & 0,394 & $-0,179$ & $\mathbf{0 , 4 3 1}$ \\
4. Learning & 0,325 & $\mathbf{0 , 6 5 6}$ & 0,315 & $-0,097$ \\
5. Care about clients & $\mathbf{0 , 5 2 0}$ & 0,391 & 0,151 & 0,256 \\
6. Adaptability & $\mathbf{0 , 9 0 0}$ & 0,088 & 0,113 & 0,121 \\
7. Strategic direction & $-0,053$ & $\mathbf{0 , 8 7 5}$ & $-0,117$ & $-0,080$ \\
8. Reward and incentive & 0,149 & $\mathbf{0 , 8 2 7}$ & 0,171 & 0,076 \\
9. System of control & 0,056 & $-0,102$ & $-0,242$ & $\mathbf{0 , 8 4 7}$ \\
10. Communication & 0,336 & $\mathbf{0 , 5 4 1}$ & 0,308 & 0,327 \\
11. Agreement & 0,187 & 0,391 & 0,203 & $\mathbf{0 , 5 4 5}$ \\
12. Coordination & 0,009 & 0,123 & 0,394 & $\mathbf{0 , 6 9 5}$ \\
\hline
\end{tabular}

Dimensions, which belong to certain group, are interrelated. Research showed that influence (on performance) of each group of dimensions is bigger than of single dimension. This influence is presented in Table 5 .

Table 5 reveals relationship between each group of dimensions and overall performance and employee satisfaction. These indexes were measured on 5-point scale. " 5 " means that position of investigated enterprise is very good in comparison with other companies from the same industry. The table shows, that overall performance has strong correlation with the second group of dimensions, which includes such dimensions as learning, strategic direction, reward and incentive system and communication (between subordinates and managers). Influence of the third group on performance is doubtful. Other scientists found, that involvement and cooperation are positively related with performance. So, bigger set is necessary to examine this relationship. The second group of dimensions has the biggest influence on employee satisfaction too.

Table 5. Relationship between groups of dimensions and performance measures $(\mathrm{N}=21)$

\begin{tabular}{|c|c|c|}
\hline $\begin{array}{c}\text { Groups of } \\
\text { dimensions }\end{array}$ & Overall performance & Employee satisfaction \\
\hline F1 & 0,132 & $-0,155$ \\
F2 & 0,260 & 0,283 \\
F3 & $-0,005$ & 0,211 \\
F4 & 0,022 & $-0,040$ \\
\hline
\end{tabular}

\section{Conclusions}

Organizational culture is multidimensional phenomenon, which influences enterprise success (outcomes). It is irrational to analyse all dimensions when investigating its influence on performance, because number of them is too big. After picking out the dimensions, which influence performance most of all, it became clear, that some of them are similar by their content; therefore it is unclear if they are the same or different dimensions. Refusing broad meaning having dimensions and ascribing smaller ones to broader group can decrease number of dimensions. Content analysis and hierarchical structuring method were used to unify the extent of dimensions and to decrease their number. Such methods help to eliminate the double relationship between dimensions.

By using these methods number of dimensions was decreased from 25 to 12 . Removed dimensions do not disappear. They are reflected in other ones. The final list includes the following dimensions: 1 ) involvement, 2) cooperation (collaboration), 3) transmission of information, 4) learning, 5) care about clients, 6) adaptability, 7) strategic direction, 8) reward and incentive system, 9) system of control, 10) communication, 11) agreement, 12) coordination and integration. A questionnaire was made based on this list. It can be called as modified instrument of organizational culture assessment, because existing culture measurement instruments were under consideration. This instrument can be used for further investigations of organizational culture and its influence on success.

It is stated in the literature, that organizational culture can be measured. Measurement is objective. Assessment, in opposite, is subjective. Therefore concept of assessment is more precise.

The questionnaire was sent to Lithuanian companies seeking to examine the relationship between dimensions. Survey of 23 companies shows, that dimensions are interrelated. It was established, that communication, reward and incentive influence other dimensions most of all.

Factor analysis showed, that dimensions fall into 4 groups. One group is directed toward internal processes of organization, second one includes internal systems, third one is directed toward outside and the fourth one is made from different dimensions. This states, that bigger sample is necessary to examine the dependencies of dimension to certain groups.

Relationship between each group and performance and also employee satisfaction were examined too. Research results show, that both of them are most related with strategic direction, learning, fair reward and support. 


\section{Appendix}

\section{Questionnaire of dimensions of organizational culture}

\begin{tabular}{|c|c|}
\hline Dimension & Statement (item) \\
\hline Involvement & $\begin{array}{l}\text { 1. All employees have favourable conditions for decision making and for giving various ideas, suggestions, notes and so on } \\
\text { 2. There are created good conditions for the interesting work, therefore employees get used to their work willingly } \\
\text { 3. Rituals and traditions of enterprise unite employees to work further effectively }\end{array}$ \\
\hline $\begin{array}{l}\text { Cooperation } \\
\text { (collaboration) }\end{array}$ & $\begin{array}{l}\text { 4. Managers consult subordinates (they collaborate) } \\
\text { 5. Teamwork is used more often than individual work, especially when solving important questions or projects } \\
\text { 6. When problems, difficulties or questions arise, employees solve them more individually than by consulting other ones }\end{array}$ \\
\hline $\begin{array}{l}\text { Transmission of } \\
\text { information }\end{array}$ & $\begin{array}{l}\text { 7. New or other important information reaches employees in due time } \\
\text { 8. Employee is often lacking information, which is necessary to make decision or to work } \\
\text { 9. Employees (also managers) often misunderstand each other (improper transmission of information) } \\
\text { 10. Managers do not provide feedback to the employees }\end{array}$ \\
\hline Learning & $\begin{array}{l}\text { 11. It is permanently invested into knowledge and skills of employees (different courses are offered and so on) } \\
\text { 12. Managers improve themselves permanently } \\
\text { 13. Employees teach each other, share skills and knowledge } \\
\text { 14. Various investigation/analysis (e.g. of product characteristics, consumers and personnel needs) are made permanently }\end{array}$ \\
\hline Care about clients & $\begin{array}{l}\text { 15. It is enough invested into improvement of product/service quality } \\
\text { 16. Employees look after clients and satisfaction of their needs permanently } \\
\text { 17. Dissatisfaction of clients is always removed } \\
\text { 18. It is offered to the client, what enterprise thinks is better, but not this, what client desires } \\
\text { 19. Enterprise inquire customers opinion about products/ services and improvement of them and takes that into account }\end{array}$ \\
\hline Adaptability & $\begin{array}{l}\text { 20. Enterprise responds always to the changes in external environment } \\
\text { 21. Work is performed straggly, if enterprise meets serious problems } \\
\text { 22. Many problems are ignored (employees/ managers do not respond to them/they are not solved) } \\
\text { 23. Employees keep up affairs and news in domestic market, abroad and strive to improve the work } \\
\text { 24. It is difficult for employees to adapt to novelties and changes in enterprise }\end{array}$ \\
\hline Strategic direction & $\begin{array}{l}\text { 25. Enterprise has a long-term strategy, plans and goals } \\
\text { 26. Goals and plans are achieved purposefully } \\
\text { 27. Your enterprise is as leader showing direction, other enterprises "follow" it } \\
\text { 28. Work is planned so, that everybody knows what and how to do his/her job } \\
\text { 29. Vision of enterprise becomes reality little by little }\end{array}$ \\
\hline $\begin{array}{c}\text { Reward and } \\
\text { incentive system }\end{array}$ & $\begin{array}{l}\text { 30. Reward system is correct (employee is getting salary/ wage according to the results and efforts) } \\
\text { 31. It is always rewarded (in monetary or other form) for the good works, ideas, innovations and so on } \\
\text { 32. Existing punishment system is correct } \\
\text { 33. Employees are more often awarded than punished } \\
\text { 34. Managers care about welfare of employees (e.g. they are provided with free services, things and so on) }\end{array}$ \\
\hline System of control & $\begin{array}{l}\text { 35. Existing rules and norms are more directive (i.e. show direction) than restrictive } \\
\text { 36. Employees have too much freedom, they think that manager must show direction } \\
\text { 37. Managers control subordinates too much }\end{array}$ \\
\hline Communication & $\begin{array}{l}\text { 38. Managers more often ask than command } \\
\text { 39. Managers' teaching and deeds are always at variance } \\
\text { 40. Manager always strives to help and advise employee } \\
\text { 41. Communication between employees is friendly (more informal than formal) }\end{array}$ \\
\hline Agreement & $\begin{array}{l}\text { 42. Employees are unified as family } \\
\text { 43. Employees always agree about most important things, when solving questions, problems or conflicts } \\
\text { 44. Employees often do not approve of changes and resist or behave indifferently } \\
\text { 45. Employees agree about most rules, norms, values (they think these things are right) }\end{array}$ \\
\hline $\begin{array}{l}\text { Coordination and } \\
\text { integration }\end{array}$ & $\begin{array}{l}\text { 46. It is very hard to work with person from other department/ group } \\
\text { 47. Departments (groups) have difficulties when carrying out common activity, sharing information and so on } \\
\text { 48. Different departments (groups) have many common things (goals, tasks, celebrations and so on) }\end{array}$ \\
\hline
\end{tabular}

\section{References}

1. Marcoulides, G. A.; Heck, R. H. Organizational Culture and Performance: Proposing and Testing a Model. Organization science, Vol 4, No 2, May 1993, p. 209-225.

2. Schein, E. H. Organizational culture and leadership. Second Edition. San Francisco: Jossey-Bass Publishers, 1992. 418 p.

3. Nahavandi, A. \& Malekzadeh, A. R. Organizational Culture in the Management of Mergers. Westport, Connecticut, London: Quorum Books, 1993. 175 p.

4. Spivak, V. A. Organizational culture: theory and practice. SanktPeterburg: Piter, 2001. 332 p. (in Russian).
5. Van der Post, W. Z.; de Coning, T. J.; Smit, E. vd M. An instrument to measure organizational culture. South African Journal of Business Management, Vol 28, Issue 4, Dec 1997, p. $147-169$.

6. Veiga, J.; Lubatkin, M.; Calori, R.; Very, P. Measuring organizational culture clashes: A two-nation post-hoc analysis of a cultural compatibility index. Human Relations, Vol 53, Issue 4, Apr 2000, p. 539-557.

7. Sarros, J.; Gray, J.; Densten, I.; Cooper, B. The Organizational Culture Profile Revisited and Revised: An Australian Perspective. Australian Journal of Management, Vol 30, No 1, June 2005, p. 159-182. 
8. Child, J. What Determines Organization Performance? The universals vs. the it-all-depends. Organizational Dynamics, Vol 3, Issue 1, Summer 1974, p. 2-18.

9. Olie, R. Shades of Culture and Institutions in International Mergers. Organization Studies, Vol 15, Issue 3, 1994, p. 381405.

10. Denison, D. R.; Mishra, A. K. Toward a Theory of Organizational Culture and Effectiveness. Organization Science, Vol 6, No 2, March-April 1995, p. 204-223.

11. Larsson, R.; Finkelstein, S. Integrating Strategic, Organizational, and Human Resource Perspectives on Mergers and Acquisitions: A Case Survey of Synergy Realization. Organization Science: A Journal of the Institute of Management Sciences, Vol 10, No 1, Jan/Feb. 1999, p. 1-26.

12. Kangis, P.; Williams, D.; Gordon, S. Organisational climate and corporate performance: an empirical investigation. Management Decision, Vol 38, Issue 8, 2000, p. 531-540.

13. Horwitz, F. M.; Andersen, K.; Bezuidenhout, A.; Cohen, S.; Kirsten, F.; Mosoeunyane, K.; Smith, N.; Thole, K.; van Heerden, A. Due diligence neglected: managing human resourses and organizational culture in mergers and acquisitions. South African Journal of Business Management, Vol 33, Issue 1, Mar 2002, p. 1-10.

14. Nahm, A. Y.; Vonderembse, M. A.; Koufteros, X. A. The Impact of Organizational Culture on Time-Based Manufacturing and Performance. Decision Sciences, Vol 35, Issue 4, Fall 2004, p. 579-607.

15. Denison, D. R. What is the difference between organizational culture and organizational climate? A native's point of view on a decade of paradigm wars. Academy of Management Review, Vol 21, Issue 3, Jul. 1996, p. 619-654.

16. Lee, S. K. J.; Yu K. Corporate culture and organizational performance. Journal of Managerial Psychology, Vol 19, No 4, 2004, p. 340-359.

17. Koys, D. J. The effects of employee satisfaction, organizational citizenship behavior, and turnover on organizational effectiveness: a unit-level, longitudinal study. Personnel Psychology, Vol 54, Issue 1, Spring 2001, p. 101114.

18. Onken, M. H. Temporal elements of organizational culture and impact on firm performance. Journal of Managerial Psychology, Vol 14, Issue 3/4, 1999, p. 231-243.

19. Sønrensen, J. B. The Strength of Corporate Culture and the Reliability of Firm Performance. Administrative Science Quarterly, Vol 47, Issue 1, Marc 2002, p. 70-91.

20. Denison, D. R.; Neale, W. S. Denison Organizational Culture Survey. Aviat, Ann Arbor, MI, 1996.

21. Fey, C. F.; Denison, D. R. Organizational Culture and Effectiveness: Can American Theory Be Applied in Russia? Organization Science: A Journal of the Institute of Management Sciences, Nov/Dec, Vol 14, 2003, p. 686-706.

22. Carmeli, A. The Link Between Organizational Elements, Perceived External Prestige and Performance. Corporate Reputation Review, Vol 6, Issue 4, Winter 2004, p. 314-331.

23. Van der Post, W. Z.; de Coning, T. J.; Smit, E. M. The relationship between Organisational culture and financial performance: some South African evidence. South African Journal of Business Management, Vol 29, Issue 1, Mar 1998, p. 30-40.

24. Park, W. The Corporate Culture Change Campaigns in Korea: Lessons from Their Failures. Asia Pacific Business Review, Summer, Vol 7, Issue 4, 2001, p. 89-110.

25. Vaitkūnaite, V. Analysis of views about organizational culture. In: Proceedings of conference "Business, Management,
Studies' 05", Vilnius, 10th November 2005. Vilnius: Technika, 2006 (in Lithuanian) (in Press).

26. Weber, R. A.; Camerer, C. F. Cultural Conflict and Merger Failure: An Experimental Approach. Management Science, Vol 49, Issue 4, Apr 2003, p. 400-415.

27. Ginevičius, R.; Podvezko, V. Formation of multiple criteria system of indexes. Business: theory and practice, Vol IV, No 4, 2005, p. 199-207 (in Lithuanian).

28. Gordon, G. G.; DiTomaso, N. Predicting corporate performance from organizational culture. Journal of Management Studies, Vol 29, Issue 6, Nov 1992, p. 783-798.

29. Marks, M. L. Consulting in mergers and acquisitions. Journal of Organizational Change Management, Vol 10, Issue 3, 1997, p. 267-279.

30. Love, P.; Gibson, S. Hidden sore points that can thwart a culture match. Mergers \& Acquisitions: The Dealermaker's Journal, Vol 33, Issue 6, May/Jun 1999, p. 51-57.

31. Hofstede, G.; Neuijen, B.; Ohayv, D. D.; Sanders, G. Measuring organizational cultures: A qualitative and quantitative study across twenty cases. Administrative Science Quarterly, Jun., Vol 35, Issue 2, 1990, p. 286-316.

32. Frank, K. A.; Fahrbach, K. Organizational culture as a Complex System: Balance and Information in Models of Influence and Selection. Organization Science, Vol 10, No 3, 1999, p. 253-277.

33. Rodriguez, S. D.; Perez, J. F. M.; Val, M. P. An empirical study about the effect of cultural problematic on organizational learning in alliances. The Learning Organization: An International Journal, Vol 10, No 3, 2003, p. 138-148.

34. Carleton, J. R.; Lineberry, C. S. Achieving Post-Merger Success: A Stakeholder's Guide to Cultural Due Diligence, Assessment, and Integration. New York: John Wiley\&Sons, Inc., 2004. 213 p.

35. Barvydienè, V.; Kasiulis, J. Psychology of management. Kaunas: Technologija, 1998. 163 p. (in Lithuanian).

36. Bjerke, B.; Elgar, E. Business Leadership and Culture: National Management Styles in the Global Economy. Cheltenham: Edward Elgar, 1999. 287 p.

37. Oh, E. The value of corporate culture. Malaysian Business. Kuala Lumpur, Nov. 1, 2000, p. 50-51.

38. Cole, G. A. Management: Theory and Practice. Fith edition. London: DP Publications, 1996. 423 p.

39. Diamond, M. A. The Unconscious Life of Organizations: Interpreting Organizational Identity. Westport, Connecticut London: Quorum Books Fairholm, 1993. 256 p.

40. Lemon, M.; Sahota, P. S. Organizational Culture as a knowledge Repository for Increased Innovative Capacity. Technovation, Vol 24, 2004, p. 483-498.

41. Jucevičius, R. Strategic development of organizations. World Lithuanians centre of culture, science and education, 1998. 433 p. (in Lithuanian).

42. Smit, I. Assessment of Cultures: a Way to Problem Solving or a Way to Problematic Solutions? In: The International Handbook of Organizational Culture and Climate. Chichester, New York, Weinheim, Brisbane, Singapore, Toronto: JohnWilley\&Sons, LTD, 2001, p. 165-180.

43. Sparrow, P. R. Developing Diagnostics for High Performance Organization Cultures. In: The International Handbook of Organizational Culture and Climate. Chichester, New York, Weinheim, Brisbane, Singapore, Toronto: JohnWilley \& Sons, LTD, 2001, p. 85-103.

44. Campbell, T.; Cairns, H. Developing and Measuring the Learning Organization. Industrial \& Commercial Training, Vol 26, Issue 7/8, 1994, p. 10-15. 
45. Wache, T.; Brammer D. Corporate identity as universal strategy. Wiesbaden: Deutscher Universitäts-Verlag, 1993. 287 p. (in German).

46. Weber, Y.; Shenkar, O.; Raveh, A. National and corporate cultural fit in mergers/acquisitions: An exploratory study. Management Science, Vol 42, Issue 8, Aug 1996, p. 12151227.

47. Miller, R. How Culture Affects Mergers and Acquisitions. Industrial Management, Vol 42, Issue 5, Sep/Oct 2000, p. $22-27$.

48. Weber, Y.; Pliskin, N. The effects on information systems integrationa and organizational culture on firm's effectiveness. Information \& Management, Vol 30, 1996, p. 81-90.

49. Cole, G. A. Strategic Management: Theory and Practice. 2 nd Ed. London: Letts Educatoinal, 1997. 244 p.

50. Roger, M. How culture Affects Mergers and Acquisitions. Industrial Management, Vol 42, Issue 5, Sep/Oct 2000, p. 22-27.

51. Garmendia, J. A. The Impact of Corporate Culture on Company Performance. Current Sociology, Vol 52, No 6, November, 2004, p. 1021-1038.

52. Shearer, C. S.; Hames, D. S.; Runge, J. B. How CEOs influence organizational culture following acquisitions. The Leadership\&Organizational Development Journal, Vol 22, No 3, 2001, p. 105-113.

53. Somers, M. J.; Bird, K. Managing the Transition Phase of Mergers. Journal of Managerial Psychology, Nov., Vol 5, Issue 4, 1990, p. 38-42.
54. Kogelheide, B. Development of realistic organizational structures: life cycle oriented analysis. Wiesbaden: Deutscher Universitäts-Verlag, 1992. 552 p. (in German)

55. Moorhead, G.; Griffin, R. W. Organizational behavior. Second edition. Boston: Houghton Mifflin Company, 1989. 807 p.

56. Yen, G.; Liao, Nelson N. H. On Acculturation in Business Mergers: Empirical Findings from a Commercial Bank's Opinion Survey in Taiwan. Review of Pacific Basin Financial Markets \& Policies, Jun., Vol 6, Issue 2, 2003, p. 141-166.

57. Goll, I.; Sambharya, R. B. Corporate Ideology, Diversification and Firm Performance. Organization Studies, Vol 16, Issue 5, 1995, p. 823-846.

58. Kowalczyk, S. J.; Pawlish, M. J. Corporate Branding through external Perception of Organizational Culture. Corporate Reputation Review, Vol 5, No 2/3, 2002, p. 159-174.

59. Lewis, D. S. Organizational Change: Relationship between Reactions, Behaviour and Organizational Performance. Journal of Organizational Change Management, Vol 7, No 5, 1994, p. 41-55.

60. Baker, M. J. Research Methods. Marketing Review, Vol 3, Issue 2, Winter, 2002, p. 167-193.

51. Ginevičius, R. Hierarchical structuring of complex phenomena and values by succesive comparison of particular criteria. Business: theory and practice, Vol IV, No 4, 2003, p. 147-154 (in Lithuanian). 